\title{
Pengaruh Implantasi Subkutan Logam Kobalt Kromium sebagai Bahan Alternatif Mini Screw Orthodontics terhadap Reaksi Jaringan Kelinci Albino
}

\author{
Ananto Ali Alhasyimi, Siti Sunarintyas, dan Marsetyawan HNE Soesatyo \\ *Program Studi Master IImu Kedokteran Gigi, Fakultas Kedokteran Gigi, Universitas Gadjah Mada, Yogyakarta, Indonesia \\ **Bagian Biomaterial, Fakultas Kedokteran Gigi, Universitas Gadjah Mada, Yogyakarta, Indonesia \\ ***Bagian Histologi dan Biologi Sel, Fakultas Kedokteran, Universitas Gadjah Mada, Yogyakarta, Indonesia \\ *J. Denta no.1 Sekip Utara, Yogyakarta, Indonesia; e-mail: anantoali@yahoo.co.id
}

\begin{abstract}
ABSTRAK
Mini screw orthodontics merupakan alat yang digunakan dalam perawatan ortodonsia untuk kasus yang membutuhkan absolute anchorage. Mini screw yang tersedia terbuat dari logam nikel titanium atau stainless steel yang pada beberapa pasien menyebabkan reaksi pada jaringan. Uji implantasi adalah uji yang dilakukan untuk menentukan biokompatibilitas medical device yang berkontak langsung dengan jaringan hidup. Respon jaringan terhadap jejas pasca implantasi mempengaruhi derajat pembentukan jaringan granulasi, reaksi benda asing, dan fibrosis. Penelitian ini bertujuan untuk mengetahui efek lokal implantasi kobalt kromium sebagai alternatif bahan mini screw orthodontics terhadap jaringan subkutan kelinci albino. Subjek penelitian berupa 20 ekor kelinci jantan albino yang digunakan untuk 2 kelompok (perlakuan dan kontrol negatif). Kobalt kromium dibuat lempengan diameter $10 \mathrm{~mm}$ dan ketebalan $1 \mathrm{~mm}$. Pada kelompok perlakuan, material diimplankan pada jaringan subkutan dorsum kelinci dengan insisi sampai terbentuk poket subkutan, dasar poket tidak lebih dari $10 \mathrm{~mm}$ dari garis awal insisi dan dilakukan suturing. Kelompok kontrol hanya dilakukan incisi kemudian disuturing. Secara makroskopis 24 jam pasca implantasi, daerah implan diamati terjadinya edema, hematoma, enkapsulasi dan tanda-tanda inflamasi. Evaluasi secara mikroskopis pada hari ke 14 pasca implantasi, diamati perubahan histopatologis infiltrasi sel-sel inflamasi, kemudian rerata hasil diuji dengan uji independent sample t-test untuk mengetahui apakah ada perbedaan jumlah sel-sel inflamasi pada kelompok perlakuan dan kontrol. Hasil pengamatan makroskopis, kelompok perlakuan maupun kontrol hanya terlihat tanda inflamasi ringan berupa eritema. Rerata dan Simpangan baku jumlah PMN, limfosit, sel plasma, makrofag, giant cell, neovaskularisasi, fibrosis kobalt kromium dan kontrol berturut turut yaitu $(0,6 \pm 0,49 ; 0,7 \pm 0,48) ;(0,9 \pm 0,87 ; 1,0 \pm 0,67) ;(0,6 \pm 0,24 ; 0,6 \pm 0,21) ;(1,4 \pm$ $0,84 ; 0,9 \pm 0,74) ;(0,5 \pm 0,27 ; 0) ;(0,6 \pm 0,33 ; 0,7 \pm 0,48) ;(0,5 \pm 0,27 ; 0,1 \pm 0,02)$. Hasil $t$-test menunjukkan perbedaan yang tidak signifikan $(p>0,05)$ pada 6 parameter inflamasi sedangkan parameter giant cell menunjukkan perbedaan yang signifikan $(p<0,05)$. Kesimpulan penelitian ini adalah implantasi subkutan logam kobalt kromium menyebabkan reaksi jaringan berupa infiltrasi giant cell selama 14 hari pasca implantasi sebagai respon tehadap benda asing.
\end{abstract}

Maj Ked Gi Ind. Juni 2015; 1(1): hal 94-101

Kata kunci: mini screw orthodontics, implantasi, kobalt kromium, reaksi jaringan

ABSTRACT: Effect Of Subcutaneous Implantation Of Cobalt Chromium As An Alternative Material For Mini Screw Orthodontics Against Albino Rabbit's Tissue. Mini screw orthodontics is an instrument which is used in orthodontic treatment for some cases that require absolute anchorage. Available mini screws are made of nickel titanium or stainless steel alloy which in some patients may cause a reaction to the tissues. Implantation test is a test performed to determine the biocompatibility of medical devices that are directly contacted to the living tissue. Tissue response to injury after implantation affects the degree of formation of granulation tissue, foreign body reaction, and fibrosis. The aim of this study is to determine the local effect of implantation of cobalt chromium as an alternative material for mini screw orthodontic against the subcutaneous tissue of albino rabbits. The subjects of study were 20 male albino rabbits divided into two groups (treatment and negative control groups). Cobalt chromium was made in the form of discs with $10 \mathrm{~mm}$ in diameter and $1 \mathrm{~mm}$ in thickness. In the treatment group, the material was implanted in the subcutaneous tissue of the dorsum of the rabbits with an incision to form a subcutaneous pocket. The pocket base was not more than $10 \mathrm{~mm}$ from the initial line of incision then suturing was performed. The control group only had incision then sutured to maintain aseptic conditions. Macroscopically 24 hours after implantation, the implant area was observed related to the occurrence of oedema, haematoma, encapsulation and signs of inflammation. The evaluation on day 14 post-implantation shows the histopathologic changes observed by the infiltration of inflammatory cells types. The average of the results was analyzed using independent sample t-test. The results of the macroscopic observation shows that the treatment and control group were only seen of mild inflammatory signs included erythema. The mean and standard deviation of the amount of PMN, lymphocyte, plasma cells, macrophage, giant cell, neovascularisation, and fibrosis from cobalt chromium and control groups were (0.6 $\pm 0.49 ; 0.7 \pm 0.48) ;(0.9 \pm 0.87 ; 1.0 \pm 0.67) ;(0.6 \pm 0.24 ; 0.6 \pm 0.21) ;(1.4 \pm 0.84 ; 0.9 \pm 0.74) ;(0.5 \pm$ $0.27 ; 0) ;(0.6 \pm 0.33 ; 0.7 \pm 0.48) ;(0.5 \pm 0.27 ; 0.1 \pm 0.02)$. The results of t-test show a significant difference in giant cell $(p<0.05)$, while the six others did not $(p>0.05)$. The conclusion of this study is that the cobalt chromium alloy can affect the subcutaneous tissue by inducing giant cell infiltration on day 14 post-implantation as the result of foreign body reactions. Maj Ked Gi Ind. Juni 2015; 1(1): hal 94-101

Keywords: mini screw orthodontics, implantation, cobalt chromium, tissue response 


\section{PENDAHULUAN}

Perkembangan ilmu kedokteran gigi khususnya bidang kedokteran gigi estetik berkembang pesat sejalan dengan meningkatnyakesadaran masyarakat terhadap penampilan. Perawatan ortodonsia adalah salah satu jenis perawatan kedokteran gigi untuk memperbaiki maloklusi dan ketidaknormalan gigi dari susunan gigi geligi sehingga dapat meningkatkan segi estetis serta fungsional regio dentofasial. ${ }^{1}$ Mini screw orthodontics merupakan alat yang sering digunakan dalam kasus-kasus yang membutuhkan absolute anchorage seperti intrusi, ekstrusi, distalisasi, protraksi, molar uprighting, koreksi midline dan koreksi occlusal plane dalam perawatan ortodonsia. ${ }^{2,3}$

Australian Society of Orthodontics (2013) menyatakan bahwa mini screw orthodontics yang beredar di pasaran terdiri dari bahan logam campur nikel titanium alloy atau stainless steel. Belum ada mini screw orthodontics yang terbuat dari bahan logam campur kobalt kromium. Kobalt kromium bersifat high temperatur resistance metal super alloy yaitu memiliki melting points (titik leleh) paling tinggi dan kurva stress-rupture yang lebih datar sehingga menghasilkan kemampuan menahan dan menyerap tekanan yang lebih baik pada suhu mutlak yang lebih tinggi dibandingkan logam jenis nikel titanium atau stainless steel. ${ }^{4}$ Ketertarikan terhadap penggunaan logam campur kobalt kromium timbul karena logam campur ini mempunyai banyak keuntungan dalam penggunaannya sebagai bahan dental casting yaitu mempunyai sifat sifat mekanis yang baik, resisten terhadap korosi, relatif ringan, dan harga yang lebih murah dibandingkan dengan jenis logam campur dari emas. ${ }^{5}$ Selain itu, kobalt kromium mempunyai sifat resisten terhadap korosi pada lingkungan fisiologis yang lebih baik jika dibandingkan logam stainless steel karena kandungan kromium yang cukup tinggi. ${ }^{6}$ Kobalt kromium memiliki nilai range kekerasan sebesar 345,24 \pm 11,9 VHN (Vickers Hardness Number) yang sesuai dengan standar ASTM F75 untuk kekerasan material implan, yaitu sekitar 276-384,6 VHN. ${ }^{7}$ Kobalt kromium mempunyai tensile strength (fracture toughness dan fatique strength) yang paling baik diantara jenis logam lain sehingga tidak mudah retak dan mampu menahan beban dinamis yang berlangsung secara terus-menerus dalam jangka waktu yang lama saat diaplikasikan sebagai bahan implan. ${ }^{8}$

Uji implantasi merupakan salah satu rangkaian dari uji biokompatibilitas untuk menguji sampel material yang akan berkontak dengan jaringan lunak atau tulang dan untuk mengevaluasi kemampuan suatu material dapat menimbulkan reaksi inflamasi. ${ }^{9}$ Respon inflamasi biasanya terjadi karena biomaterial dikenali sebagai benda asing sehingga host melakukan mekanisme pembersihan kontaminan untuk meminimalisasi infeksi melalui fagositosis. Inflamasi setelah implantasi biomaterial diikuti oleh penyembuhan area implantasi, baik melalui regenerasi sel parenkimal yang asli, pembentukan jaringan parut fibroblastik, maupun keduanya..$^{10}$

Respon inflamasi juga bisa terjadi sebagai akibat dari pelepasan ion ion logam karena proses korosi. Kondisi rongga mulut yang asam dapat meningkatkan proses terjadinya pelepasan ion yang dapat menimbulkan toksisitas melalui mekanisme mempengaruhi enzimatik sel atau toksis secara langsung melalui infiltrasi membran. ${ }^{11}$ Ion logam yang terlepas berpengaruh terhadap metabolisme seluler dengan menghambat aktivitas enzim dehidrogenase dan adenosin trifosfat (ATP). ${ }^{9}$ Berdasarkan penelitian Kakkar dkk., ${ }^{12}$ ion logam dapat merusak bagian internal dan eksternal membran sel, kehilangan material matriks, perubahan pada lipatan (cristae) mitokondria, dan kerusakan mitokondria. Efek toksik dari pelepasan ion memungkinkan terjadinya reaksi inflamasi.

Penelitian ini menggunakan kelinci albino (Oryctolagus cuniculus) sebagai hewan coba karena mempunyai respon immunologis dan patologis terhadap stress dan patogen yang mirip dengan manusia. ${ }^{13}$ Penelitian ini bertujuan untuk mengkaji pengaruh implantasi subkutan logam kobalt kromium sebagai bahan dasar mini screw orthodontics terhadap reaksi jaringan dorsum kelinci albino.

\section{METODE PENELITIAN}

Surat ijin kelayakan etik diperoleh dari Komisi Etik Penelitian Kedokteran dan Kesehatan Fakultas Kedokteran Universitas Gadjah Mada Yogyakarta 
(Medical and Health Research Ethics Comittee (MHREC), Ministry of Education and Culture Faculty of Medicine, Gadjah Mada University) Ref: KE/FK/929/EC. Hewan coba yang digunakan adalah kelinci jantan albino peranakan lokal, berumur 12-13 minggu dengan berat badan 10002000 gram. Kelinci dibagi menjadi 2 kelompok perlakuan yaitu kelompok kontrol negatif dan kelompok perlakuan. Masing-masing kelompok berjumlah 10 ekor. Material logam kobalt kromium (Remanium ${ }^{\circledR}$ GM 800, Dentaurum, Germany) yang dibuat lempengan dengan ukuran diameter $10 \mathrm{~mm}$ dan ketebalan $1 \mathrm{~mm}$ sebagai bahan uji dilakukan sterilisasi dengan autoclave suhu $134^{\circ} \mathrm{C} \pm 15$ menit selanjutnya direndam menggunakan metanol \pm 30 menit. $^{14}$

Punggung kelinci ditandai ukuran $4 \times 5 \mathrm{~cm}$ dan dicukur sampai bersih. Selanjutnya, dioleskan alkohol $70 \%$ untuk mengurangi kontaminasi. Kelinci dianestesi menggunakan ketamin dengan dosis 15 $\mathrm{mg} / \mathrm{kgBB}$ secara intravena pada vena marginalis menggunakan jarum spuit tuberculin $1 \mathrm{cc}$ dan ketamine. Setelah kelinci teranestesi, punggung yang sudah ditandai dilakukan insisi pada midline dorsum sepanjang $1 \mathrm{~cm}$ sampai terbentuk poket subkutan berupa diseksi tumpul, dengan dasar tidak lebih dari $10 \mathrm{~mm}$ dari garis awal insisi. Kelompok perlakuan diberi perlakuan implantasi logam kobalt kromium kemudian area perlukaan dilakukan suturing sebanyak 3 jahitan interrupted dan diaplikasikan iodine sebagai bahan antiseptik. Kelompok kontrol negatif tidak diberi perlakuan implantasi, tetapi tetap mendapatkan perlakuan bedah insisi dan suturing. ${ }^{14}$

Selanjutnya kelinci ditempatkan pada kandang individual dan diamati gejala serta perubahan sikap dan kemungkinan kematian selama 24 jam. Kondisi kesehatan umum kelinci diobservasi dan jika ditemukan perubahan lokal, sistemik, maupun abnormalitas perilaku dicatat. Kemudian diamati juga apakah terdapat edema, hematoma, enkapsulasi dan tanda tanda inflamasi. Kelinci dikorbankan pada hari ke 15 (minggu ke2) pasca implantasi untuk mendapatkan preparat histologis. Evaluasi secara mikroskopis dilakukan oleh 2 independent observer secara blinding method dengan mikroskop cahaya kemudian dihitung dengan handy tally counter. Pengamatan dan penghitungan sel-sel inflamasi (sel PMN, limfosit, sel plasma, makrofag, giant cell, nekrosis), neovaskularisasi, fibrosis, dan infiltrasi lemak dilakukan di sekitar daerah implantasi. Pengamatan dilakukan pada 10 lapang pandang pada mikroskop cahaya dengan perbesaran $400 x$ ( $40 x$ lensa objektif, 10x lensa okuler). Kemudian hasil rerata jumlah sel-sel inflamasi diuji normalitas menggunakan uji Saphiro wilk dan diuji homogenitas. Bila data terdistribusi normal dan variansinya homogen, maka dilanjutkan dengan uji independent sample t-test untuk mengetahui apakah ada perbedaan jumlah sel-sel inflamasi pada kelompok perlakuan dan kontrol.

\section{HASIL PENELITIAN}

Pengamatan dilakukan secara makroskopis dan mikroskopis. Pengamatan makroskopis menunjukkan tidak ada gejala serta perubahan sikap dan kematian kelinci selama 24 jam pada kedua kelompok yaitu kelompok implantasi kobalt kromium dan kontrol negatif. Kondisi kesehatan umum kelinci tidak ditemukan perubahan sistemik, abnormalitas perilaku, dan perubahan lokal. Gambaran klinis area insisi 24 jam pasca implantasi dapat dilihat pada Gambar 1. Gambar 1 menunjukkan bahwa baik kelompok perlakuan maupun kontrol hanya terlihat tanda inflamasi ringan berupa eritema (tanda panah). (lihat Gambar 1)

Pengamatan parameter inflamasi secara mikroskopis dilakukan menggunakan blinding method. Nilai rerata dan simpangan baku parameter sel inflamasi kelompok kobalt kromium dan kontrol selama 14 hari dapat dilihat pada Tabel 1. Tabel 1 menunjukkan bahwa nilai rerata dan simpangan baku parameter inflamasi kedua kelompok selama 14 hari implantasi menunjukkan perbedaan. Kelompok implantasi kobalt kromium menunjukkan rerata yang lebih besar daripada kelompok kontrol untuk parameter makrofag, giant cell, dan fibrosis. Rerata sel plasma kedua kelompok menunjukkan jumlah yang sama. (lihat Tabel 1) 


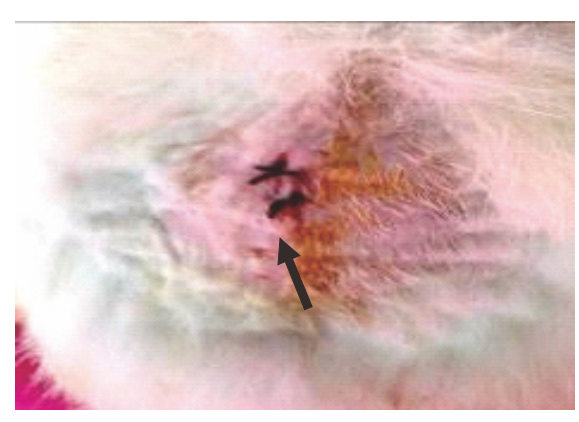

(A)

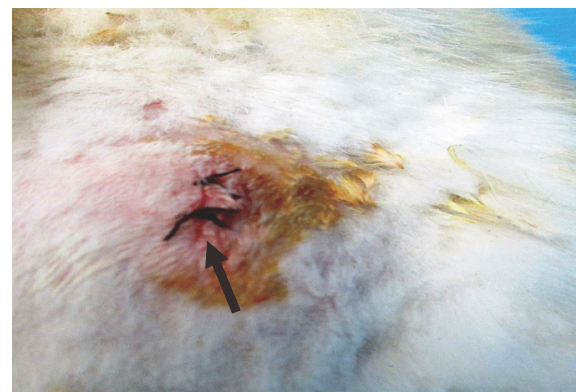

(B)

Gambar 1. Gambaran makroskopis area insisi 24 jam pasca implantasi. Pada kelompok perlakuan (A) maupun kontrol negatif (B) terlihat tanda inflamasi ringan berupa eritema (tanda panah).

Tabel 1. Hasil rerata dan simpangan baku jumlah sel parameter inflamasi implantasi subkutan logam kobalt kromium dan kontrol selama 14 hari

\begin{tabular}{ccc}
\hline \multirow{2}{*}{ Parameter inflamasi } & \multicolumn{2}{c}{ Sampel Uji } \\
\cline { 2 - 3 } & Kobalt kromium & Kontrol \\
\hline Polimorfonuklear & $0,6 \pm 0,49$ & $0,7 \pm 0,48$ \\
Limfosit & $0,9 \pm 0,87$ & $1,0 \pm 0,67$ \\
Sel Plasma & $0,6 \pm 0,24$ & $0,6 \pm 0,21$ \\
Makrofag & $1,4 \pm 0,84$ & $0,9 \pm 0,74$ \\
Giant cell & $0,5 \pm 0,27$ & 0 \\
Nekrosis & 0 & 0 \\
Neovaskularisasi & $0,6 \pm 0,33$ & $0,7 \pm 0,48$ \\
Fibrosis & $0,5 \pm 0,27$ & $0,1 \pm 0,02$ \\
Infiltrat Lemak & 0 & 0 \\
\hline
\end{tabular}

Tabel 2. Rangkuman hasil independent sample t-test reaksi jaringan subkutan terhadap implantasi subkutan logam kobalt kromium

\begin{tabular}{cc}
\hline Parameter inflamasi & Signifikansi \\
\hline Polimorfonuklear & 0,13 \\
Limfosit & 0,15 \\
Sel Plasma & 0,43 \\
Makrofag & 0,35 \\
Giant cell & $0,00^{\star *}$ \\
Sel Nekrosis & - \\
Neovaskularisasi & 0,32 \\
Fibrosis & 0,10 \\
Infiltrat Lemak & - \\
\hline
\end{tabular}

${ }^{* *}$ Nilai $p<0.05=$ terdapat perbedaan bermakna

Untuk mengetahui signifikansi perbedaan secara statistik rerata kedua kelompok digunakan uji independent sample t-test. Syarat uji statistik parametrik independent sample t-test adalah data berdistribusi normal dan memiliki variansi homogen.
Hasil uji normalitas Saphiro Wilk dan homogenitas semua kelompok menunjukkan $p>0,05$ yang berarti data terdistribusi normal dan variansi homogen. Berdasarkan hasil uji normalitas maka data penelitian memenuhi syarat untuk dilakukan uji independent sample t-test. Rangkuman hasil uji independent sample t-test tercantum dalam Tabel 2. Tabel 2 menunjukkan perbedaan yang signifikan $(p<0,05)$ pada parameter giant cell antara kelompok perlakuan dan kontrol. (lihat Tabel 2)

Pengamatan secara mikroskopis 14 hari pasca implantasi terlihat infiltrasi giant cell dan fibrosis pada kelompok perlakuan implantasi logam kobalt kromium (Gambar 2 dan Gambar 3). Pada kelompok kontrol negatif hanya terlihat infiltrasi sel inflamasi seperti leukosit, limfosit, sel plasma, makrofag, serta neovaskularisasi dan proliferasi sel fibroblas (Gambar 2). (lihat Gambar 2 dan Gambar 3) 


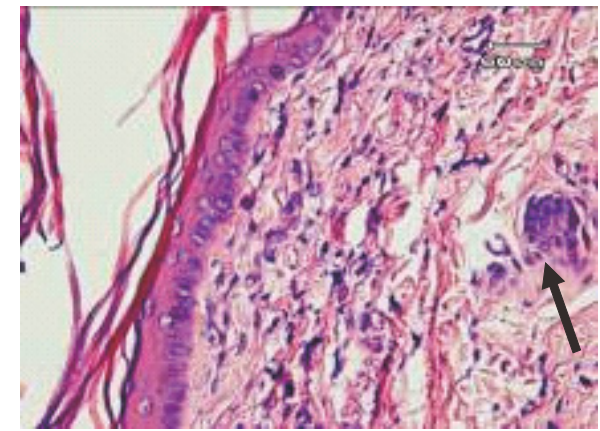

(A)

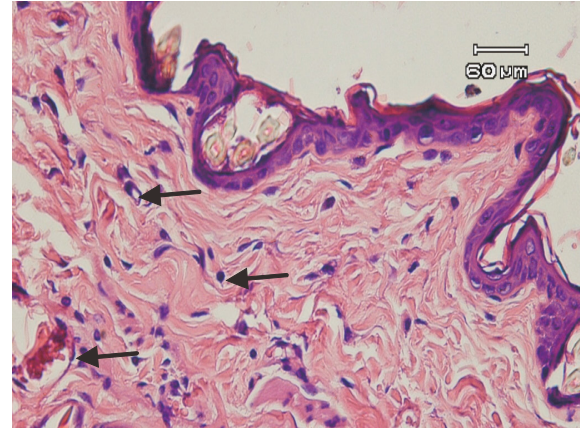

(B)

Gambar 2. Gambaran mikroskopis area insisi 14 hari pasca implantasi (perbesaran 400x). Pada kelompok perlakuan (A) tampak adanya giant cell disekitar area bekas implantasi logam kobalt kromium (tanda panah) dan pada kelompok kontrol negatif (B) terlihat neovaskularisasi serta infiltrasi sel-sel inflamasi (tanda panah).

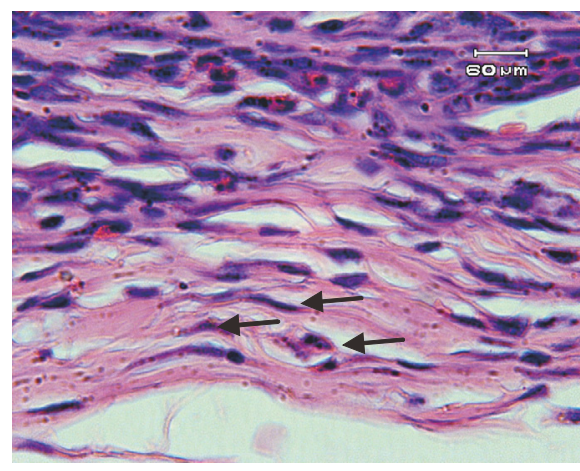

(A)

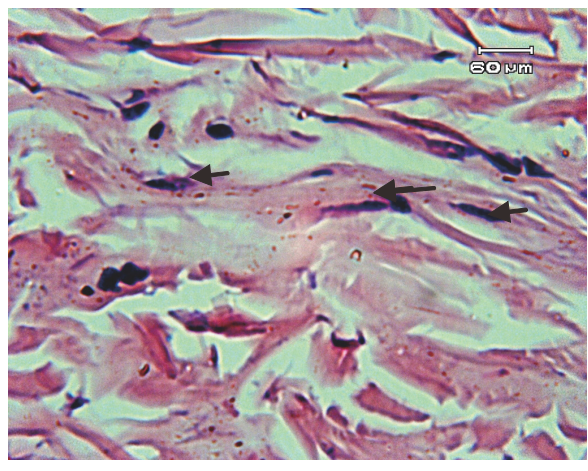

(B)

Gambar 3. Gambaran mikroskopis area insisi 14 hari pasca perlukaan (perbesaran 400x) pada kelompok perlakuan implantasi logam kobalt kromium (A) tampak adanya serabut serabut fibrin yang tipis (tanda panah) dan pada kelompok kontrol negatif (B) hanya terlihat sedikit infiltrasi sel-sel fibroblas (tanda panah).

\section{PEMBAHASAN}

Hasil pengamatan makroskopis 24 jam pasca implantasi pada kelompok perlakuan maupun kontrol hanya terlihat tanda inflamasi ringan berupa eritema. Proses implantasi dari suatu material akan menimbulkan trauma terhadap jaringan atau organ yang memicu mekanisme hemostasis. ${ }^{15}$ Hemostasis adalah proses tubuh yang secara simultan menghentikan perdarahan dari tempat yang cedera, sekaligus mempertahankan darah berada di dalam kompartemen vascular. ${ }^{16}$ Selanjutnya terjadi vasodilatasi pembuluh darah dan peningkatan permeabilitas pembuluh darah yang dimediasi oleh histamin. Dilatasi pembuluh darah mengakibatkan tekanan cairan di kapiler meningkat dan membuat warna jaringan menjadi terlihat kemerahan. ${ }^{17}$
Hasil penelitian menunjukkan rerata dan simpangan baku parameter inflamasi pada kedua kelompok terjadi reaksi inflamasi pada jaringan subkutan. Reaksi inflamasi yang terjadi pada kelompok kontrol merupakan reaksi penyembuhan luka yang terjadi setelah insisi dan proses suturing. Hal ini ditandai dengan infiltrasi sel leukosit, limfosit, sel plasma, makrofag, neovaskularisasi serta sel fibroblas pada area insisi. Proses penyembuhan luka merupakan suatu respon jaringan terhadap trauma berupa pemulihan dari integritas jaringan serta pengembalian struktur dan fungsi jaringan yang mengalami trauma. ${ }^{18}$ Saat terjadi luka, pembuluh darah akan terbuka dan terjadi reaksi hemostasis yaitu keluarnya platelet yang menyumbat pembuluh darah. ${ }^{19}$ Platelet akan menguraikan substansi proinflamasi seperti adenosine diphosphate (ADP), tissue growth factor beta (TGF- $\beta$ ), platelet- 
derived growth factors (PDGF) yang berfungsi untuk merangsang kemotaksis neutrofil, monosit, dan fibroblas ke area luka. ${ }^{20}$ Selanjutnya monosit berdifferensiasi menjadi makrofag dan melepaskan faktor pertumbuhan untuk menstimulasi proliferasi fibroblas dan angiogenesis. Limfosit datang ke daerah luka pada tahap berikutnya dan memulai fase penyesuaian respon imun. ${ }^{21,22}$ Sel plasma merupakan produk akhir dari aktivasi sel limfosit B yang mengalami diferensiasi akhir. Sel ini menghasilkan antibodi untuk melawan antigen di tempat radang. ${ }^{23}$ Fibroblas adalah sel yang bertanggung jawab untuk sintesis proteoglikan dan kolagen. ${ }^{24}$ Neovaskularisasi merupakan proses saat pembuluh darah yang telah ada sebelumnya akan mengeluarkan tunas kapiler untuk menghasilkan pembuluh darah baru yang diperlukan sebagai penyedia nutrisi bagi fibroblas, leukosit, dan keratinosit yang sedang berproliferasi. ${ }^{25}$

Hasil independent sample t-test menunjukkan perbedaan yang signifikan pada parameter giant cell mengindikasikan implantasi subkutan logam kobalt kromium berpengaruh terhadap infiltrasi giant cell secara signifikan. Setelah implantasi material, makrofag akan mempertahankan jaringan normal dengan melakukan fagositosis sel mati, debris sel, dan jasad renik lainnya. Makrofag kemudian memecahnya menggunakan lisosom. ${ }^{26}$ Bila makrofag bergerombol mengelilingi benda asing yang terlalu besar untuk difagositosis, maka makrofag akan berfusi dan meleburkan diri membentuk massa besar berinti banyak yang disebut giant cell di sekitar area implan sebagai respon host terhadap benda asing. ${ }^{27}$ Mekanisme terbentuknya giant cell disekitar area implan sebagai respon terhadap benda asing dijelaskan oleh Ward ${ }^{28}$ sebagai proses biokimiawi yang kompleks. Setelah biomaterial diimplankan ke dalam jaringan, trauma yang melibatkan jaringan vaskuler saat prosedur implantasi memicu pembentukan matriks provisional pada daerah implantasi. Matriks provisional terdiri atas fibrinogen, yang diproduksi oleh aktivasi sistem koagulasi. Selanjutnya, fibrinogen akan terikat pada permukaan material yang dikenal sebagai proses biofuling. Fibrinogen merupakan deposisi protein plasma dalam matriks ekstraseluler yang disekresikan saat terjadi peningkatan permeabilitas vaskular yang dimediasi oleh Vascular Endothelial Growth Factor (VEGF). ${ }^{29}$ Makrofag akan ditarik oleh reseptor yang disekresi oleh fibrinogen yaitu integrin mac-1 untuk berfusi menjadi multinucleated giant cell. Fibroblas akan bertransformasi menjadi myofibroblas sebagai respon sinyal dari sitokin proinflamasi Transforming Growth Factor beta (TGF- $\beta$ ) yang disekresikan multinucleated giant cell. Myofibroblas akan mensintesis prokolagen melalui aktivasi mediator smad. Mediator smad merupakan serangkaian protein intraseluler yang dikenal dapat menstimulasi fibrosis melalui jalur TGF- $\beta .^{30}$ Prokolagen kemudian mengalami proses pengikatan silang (crosslink) untuk meningkatkan kekuatan jaringan dan membentuk anyamananyaman menjadi kolagen ekstraseluler yang matang. Kolagen yang sudah matang bersama dengan matriks ekstraseluler secara bertahap membentuk kapsula kolagen fibrosa impermeabel (fibrosis). ${ }^{28}$ Keberadaan giant cell pada area implantasi hanya berlangsung dalam waktu yang sangat singkat (beberapa hari). ${ }^{16}$ Honma dan Hamasaki melaporkan bahwa giant cells akan mulai menghilang dari area implan bersamaan dengan resorbsi kapsula kolagen fibrosa melalui proses apoptosis.

Komposisi kobalt kromium selalu berbeda dari setiap produksi pabrik yang berbeda. Kobalt kromium yang digunakan pada penelitian ini adalah Remanium ${ }^{\circledR}$ GM 800 produksi Dentaurum, dengan komposisi kobalt 53,3\%, kromium $31 \%$, silika $1 \%$ serta $14,7 \%$ sisanya adalah molibdenum, tungsten, mangan dan karbon. Hasil uji energy dispersive spectrometry (EDS) Remanium ${ }^{\circledR}$ GM 800 sebelum diimplan dari ion logam $\mathrm{Co}, \mathrm{Cr}, \mathrm{Si}$ berturut turut adalah $53,16 \% ; 30,79 \% ; 1,03 \%$ dan setelah diimplan adalah $53,6 \% ; 30,89 \% ; 1,23 \%$. Hal ini mengindikasikan bahwa setelah diimplankan secara subkutan selama 14 hari, kobalt kromium tidak mengalami banyak perubahan komposisi dibandingkan dengan sebelum implan. Logam kobalt kromium akan menciptakan lapisan inert pada permukaan luar yang disebut passive layer berupa lapisan kromium oksida $\left(\mathrm{Cr}_{2} \mathrm{O}_{3}\right)$ ketika berinteraksi dengan oksigen. Passive layer inilah yang menyebabkan kobalt kromium memiliki 
resistensi terhadap korosi dengan membentuk lapisan setebal 1-4 nm yang memisahkan logam dengan lingkungan dan cairan di sekitarnya. ${ }^{31} \mathrm{Hal}$ ini mengindikasikan bahwa respon inflamasi yang terjadi pada jaringan setelah implantasi logam kobalt kromium merupakan reaksi benda asing dan bukan akibat dari pelepasan ion logam serta ion-ion logam yang terlepas dan terlarut dari logam kobalt kromium tergolong aman. Berdasarkan hasil uji implantasi tersebut dapat disimpulkan bahwa kobalt kromium (Remanium ${ }^{\circledR}$ GM 800, Dentaurum, Germany) berpotensi digunakan sebagai alternatif material mini screw orthodontics.

\section{KESIMPULAN}

Implantasi subkutan logam kobalt kromium menyebabkan reaksi jaringan berupa infiltrasi giant cell pada 14 hari pasca implantasi sebagai respon terhadap benda asing.

\section{DAFTAR PUSTAKA}

1. Iyyer BS. Bhalaji SI. Orthodontics, the Art and Science, $3^{\text {rd }}$ edition. New Delhi: Arya (Medi) Publishing House. 2006. H. 7-8

2. Motoyoshi M. Clinical Indices Orthodontic Mini-Implants. Journal of Oral Science. 2011. 53(4): 407-412.

3. Solana RM, Vico RM, Linares Al, Lagares DT, Reina ES. Miniscrew Appliances and Their Use in Orthodontics. Open Journal of Stomatology. 2013; 3: 103-108.

4. Cardarelli F. Materials Handbook: A Concise Desktop Reference. New York, USA: Springer Science and Business Media. 2008. H. 97.

5. Powers JM, Sakaguchi RL. Craig's Restorative and Dental Materials, $13^{\text {th }}$ edition. St. Iouis: Mosby Elsevier. 2012. H.119-120.

6. Shi D. Introduction to Biomaterials. Tsinghua University Press: Beijing, China. 2006. H.9495

7. Prasetyo A. Pengaruh Variasi Kandungan Silikon terhadap Korosi Paduan Kobalt (ASTM F 75) Hasil Metalurgi Serbuk dalam
Larutan Artificial Blood Plasma dengan Teknik Polarisasi Potensiodinamik dan Teknik Exposure. Tesis. Universitas Indonesia, Jakarta. 2010. H.49-51.

8. Breitbarrtr A, Ablaza V. Implant Materials dalam Grabb and Smith's Plastic Surgery, 6th Ed., Chapter 7, Lippincott Williams and Wilkins. 2007. H.78.

9. O'Brien WJ. Dental Materials and Their Selection, $4^{\text {th }}$ edition. Michigan: Quintessence Publishing Co. 2002. H.395.

10. Rochford ETJ, Richards RG, Moriarty TF. Influence of Material on the Development of Device-Associated Infections, Clinical Microbiology and Infection, 2012. 469: 1-6.

11. Behl B, Papageorgiou I, Browna C, Hall R, Tipper JL, Fisher J, Ingham E. Biological Effects of Cobalt-Chromium Nanoparticles and Ions on Dural Fibroblasts and Dural Epithelial Cells. Biomaterials, 2013. 34: 3547-58.

12. Kakkar P, Musavi S, Mehrota S. Mitochondrial Responses under Chemical Stress, Polish Journal of Environmental Studies. 2000. 9 (4): 285-290.

13. Melillo A. Rabbit Clinical Pathology. Journal of Exotic Pet Medicine, 2007. 16 (3): 135-145.

14. International Organization for Standardization. Biological Evaluation of Medical Devices - Part 6: Tests for Local Effects after Implantation. Switzerland: ISO. 2009.

15. Anderson JM. Biological Responses to Materials. Annu. Rev. Mater. Res., 2001. 31:81-110.

16. Sacher RA, McPherson RA. Tinjauan Klinis Hasil Pemeriksaan Laboratorium (terj.). Edisi ke-11. Jakarta: Penerbit Buku Kedokteran EGC. 2004. H.21.

17. Corwin EJ. Buku Saku Patofisisologi Corwin (terj.). Jakarta: Penerbit Buku Kedokteran EGC. 2009. H.14-15.

18. Kalangi SJR. Peran Kolagen pada Penyembuhan Luka, Dexa Media, 2004.17(4): 168-174. 
19. Somantri I. 2007 Perawatan Luka, Diakses dari : http://irmanthea.blogspot.com/2007/07/ definisi-luka-adalah-rusaknya.html, diunduh 21 Oktober 2014.

20. de la Torre JI. 2006. Wound Healing, Chronic Wound, Diakses dari : http://www.emedicine. com/plastic.htm, diunduh 21 Oktober 2014.

21. Diegelmann RF, Evans MC. Wound Healing: an Overview of Acute, Fibrotic and Delayed Healing, Frontiers in Bioscience. 2004; 9: 283289.

22. Tsirogiani AK, Moutsopoulus NM, MoutsopouIus HM. Wound Healing: Immunological Aspect Injury, Int J Care Injured. 2006. 37:512.

23. Sudiono J, Kurniadhi B, Hendrawan A. Djimantoro B. Ilmu Patologi. Jakarta: Penerbit Buku Kedokteran EGC. 2003; 81-93.

24. Dealey C. The Care of Wounds. A Guide for Nurses. Oxford: Blackwell Science Ltd. 2005. H.1-12.

25. Kumar V, Cotran RS, Robbins SL. Buku Ajar Patologi (terj.), Edisi 7, Jakarta: Penerbit Buku Kedokteran EGC. 2007. H.24-26.
26. Ratner BD. Reducing Capsular Thickness and Enhancing Angiogenesis Around Implant Drug Release Systems, Journal of Controlled Release. 2001; 78 (20): 211-218.

27. Fawcett DW. Buku Ajar Histologi (terj.), edisi 12, Jakarta: Penerbit Buku Kedokteran EGC. 2002. H.32-33.

28. Ward WK. a Review of the Foreign-body Response to Subcutaneously-implanted Devices: The Role of Macrophages and Cytokines in Biofouling and Fibrosis, Journal of Diabetes Science and Technology. 2008. 2(5): 768-777.

29. Mitchell R, Kumar V, Abbas AK, Robbins Basic Pathology. $8^{\text {th }}$ edition, Philadelphia: W.B. Saunders Co. 2007. H.126.

30. Gu L, Zhu YJ, Yang X, Guo ZJ, Xu WB, Tian XL. Effect of TGF-beta/Smad Signaling Pathway on Lung Myofibroblast Differentiation. Acta Pharmacol Sin. 2007; 28(3): 382-91.

31. Bellefontaine G. The Corrosion Of CoCrMo Alloys for Biomedical Applications, Thesis, School of Metallurgy and Materials, University of Birmingham. 2010. H.63-66. 